\title{
STRATIGRAFI DAN KETERDAPATAN BATUBARA PADA FORMASI LATI DI DAERAH BERAU, KALIMANTAN TIMUR
}

\author{
Oleh: \\ Sigit Maryanto \\ Pusat Survei Geologi, \\ Jl. Diponegoro 57 Bandung
}

\begin{abstract}
SARI
Beberapa lintasan stratigrafi rinci di daerah Lati, Binungan dan Sambarata telah diukur guna mengetahui keterdapatan dan kedudukan stratigrafi satuan pembawa batubara Formasi Lati di daerah Berau, Kalimantan Timur. Data stratigrafi memperlihatkan bahwa Formasi Lati yang terendapkan kala Miosen Tengah di lingkungan rawa-rawa pada hutan hujan yang berada di dataran delta hingga sungai, dengan ketebalan total terukur mencapai 400 meter.

Perlapisan batubara mulai hadir secara setempat di bagian tengah formasi, berkembang dengan baik di bagian atas formasi, dan sangat jarang dijumpai di bagian teratas formasi. Perlapisan batubara tersebut pada umumnya berwarna hitam hingga hitam kecoklatan, brightbanded hingga dull-banded, terkekarkan kuat, pecah subkonkoidal, densitas sedang, kadangkadang dengan parting atau lensa batuan silisiklastika sangat halus, dan tebalnya mencapai $650 \mathrm{~cm}$.
\end{abstract}

Kata kunci: Berau, dataran delta, hutan hujan, perlapisan tengah, tercerai.

\section{ABSTRACT}

Several detailed stratigraphic sections at Lati, Binungan and Sambarata areas have been measured to identify the occurrence and stratigraphy of coal bearing unit of Lati Formation at Berau area, East Kalimantan. Stratigraphic data show that the Lati Formation was generally deposited at Middle Miocene in wet forested swamps of delta plain to fluvial environment, with total measured thickness up to 400 meters.

The coal seams locally initiated at the middle part of the formation, well developed at the upper part of the formation, and rarely distributed at the uppermost part of the formation. These coal seams are generally black to brownish black colour, bright-banded to dull-banded, intensively cleated, subconcoidal fractured, moderate density, sometimes with very fine siliciclastics parting orlenses, and up to $650 \mathrm{~cm}$ thickness.

Keyword: Berau, delta plain, wet forest, middle seams, splitting.

\section{PENDAHULUAN}

Dalam dasawarsa terakhir ini penggunaan batubara sebagai bahan energi meningkat dengan pesatnya (Anggayana \& Widayat, 2007). Pemanfaatan batubara sebagai sumber energi dapat menjadi salah satu skenario dalam mengatasi krisis energi.

Cekungan Tarakan di Kalimantan Timur terbagi menjadi empat sub-cekungan, yaitu Tarakan, Tidung, Berau, dan Muara (Tossin \& Kadir, 1996; Gambar 1). Pembagian menjadi sub-cekungan ini didasarkan keadaan geologi dan sedimentasi pada saat batuan sedimen di lokasi tersebut diendapkan. Selain telah terbukti sebagai penghasil hidrokarbon, termasuk coalbed methane (Suwarna drr., 2006), Subcekungan Berau juga mempunyai beberapa satuan batuan yang mengandung lapisan batubara, salah satunya adalah Formasi Lati, khususnya bagian atas yang terendapkan di sungai hingga dataran delta (Suwarna \& Hermanto, 2007).

Penelitian ini bermaksud untuk mengetahui kedudukan stratigrafi perlapisan batubara yang terdapat di dalam Formasi Lati, dan bertujuan untuk menentukan lingkungan pengendapan batubara yang dijumpai. Untuk itu, maka dilakukan pengumpulan data lapangan dengan pengukuran stratigrafi rinci di tiga lokasi, yaitu Lati, Binungan, dan Sambarata (Gambar 2; Rachmansjah drr., 2003). Selain pengumpulan data lapangan, juga dilakukan pengujian laboratorium yang meliputi kimia, palinologi, dan petrografi. 
Daerah penelitian berada di Sub-cekungan Berau, tepatnya pada koordinat 117010' 117040' BT dan 02000' - 02020' LU, yang secara administratif berada di wilayah Kabupaten Berau dengan ibukota di Tanjungredeb, Propinsi Kalimantan Timur.

\section{STRATIGRAFIREGIONAL}

Tataan stratigrafi di daerah penelitian (Situmorang \& Burhan, 1995; Gambar 3), secara berurutan dimulai dari yang tertua, adalah Formasi Sembakung, Formasi Talabar, Formasi Birang, Formasi Lati, Formasi Labanan, Formasi Domaring, Formasi Sinjin, dan Aluvium.

Batuan Tersier Awal terdiri atas Formasi Sembakung, Formasi Talabar, dan Formasi Birang. Formasi Sembakung menindih takselaras batuan alas Kapur Akhir, terdiri atas batuan silisiklastika karbonatan dari lingkungan laut pada kala Eosen. Formasi Talabar terdiri atas batuan silisiklastika halus dan karbonat dari lingkungan fluviatil - laut dangkal pada kala Eosen-Oligosen. Formasi Birang menindih takselaras di atas Formasi Talabar, terdiri atas batuan silisiklastika, karbonat, dan tuf dari lingkungan laut dangkal hingga laut dalam pada kala Oligo-Miosen.
Formasi Lati (koreksi dari Formasi Latih berdasarkan nama sungai yang dipakai sebagai lokasi tipe di daerah penelitian) menindih selaras di atas Formasi Birang, terdiri atas batuan silisiklastika halus dan batubara yang pada bagian bawahnya karbonatan dari lingkungan delta, estuarin dan laut dangkal kala Miosen Awal - Miosen Tengah dengan ketebalan sekitar 800 meter. Secara berurutan Formasi Lati tertindih takselaras oleh Formasi Labanan, Formasi Domaring, dan Formasi Sinjin.

Formasi Labanan menindih takselaras di atas Formasi Lati, terdiri atas batuan silisiklastika disisipi batubara dari lingkungan fluvial pada Miosen Akhir - Pliosen. Formasi Domaring menjemari dengan Formasi Labanan, terdiri atas batuan karbonat dengan sisipan lignit dari lingkungan rawa - litoral pada kala Miosen Akhir Pliosen. Formasi Sinjin terendapkan selaras di atas Formasi Labanan dan Formasi Domaring, terdiri atas batuan volkaniklastika dari lingkungan darat pada kala Pliosen. Aluvium menindih takselaras satuan batuan yang sudah terbentuk tersebut.

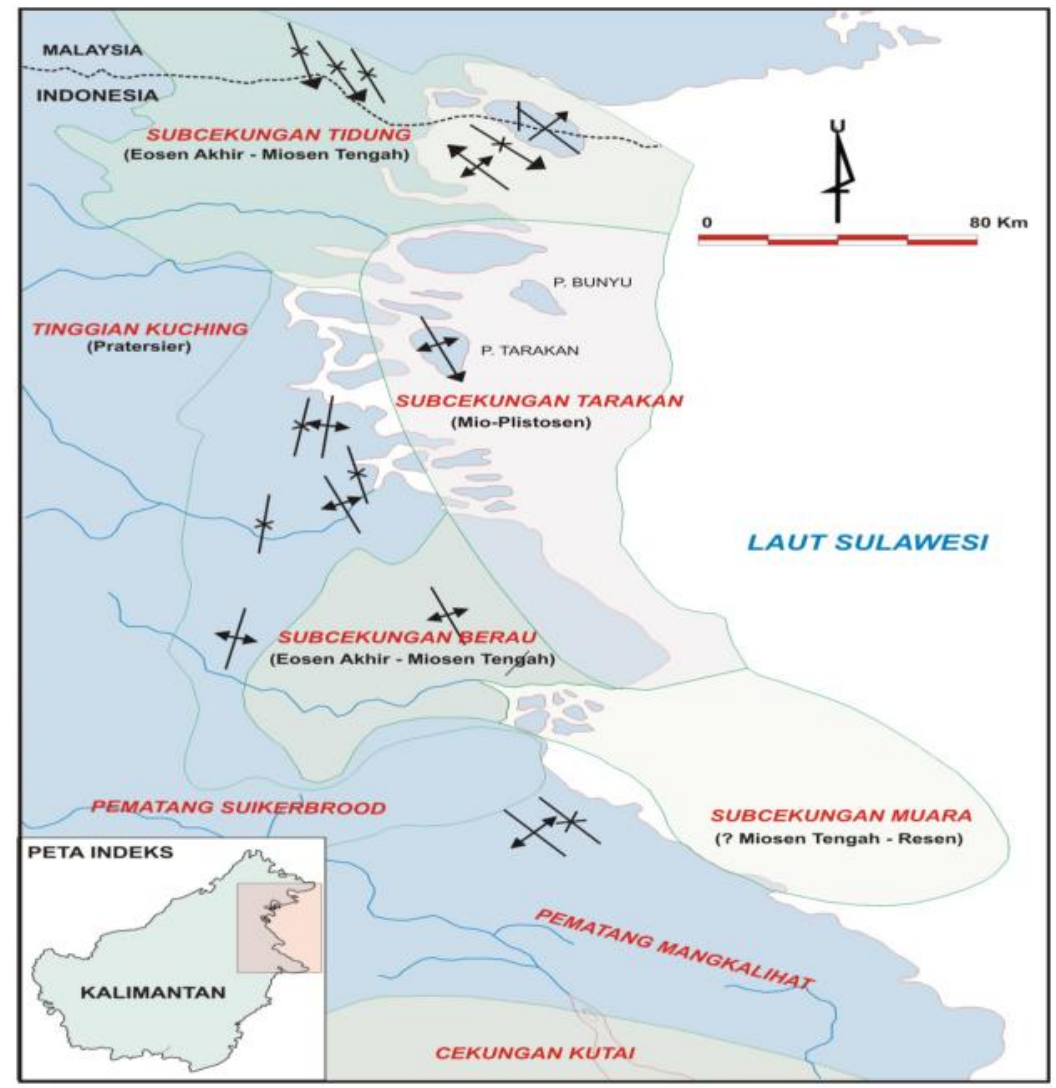

Gambar 1. Peta wilayah Cekungan Tarakan yang terbagi menjadi empat subcekungan, yaitu Tidung, Tarakan, Berau dan Muara (Tossin \& Kadir, 1996). 


\section{MAKALAH ILMIAH}

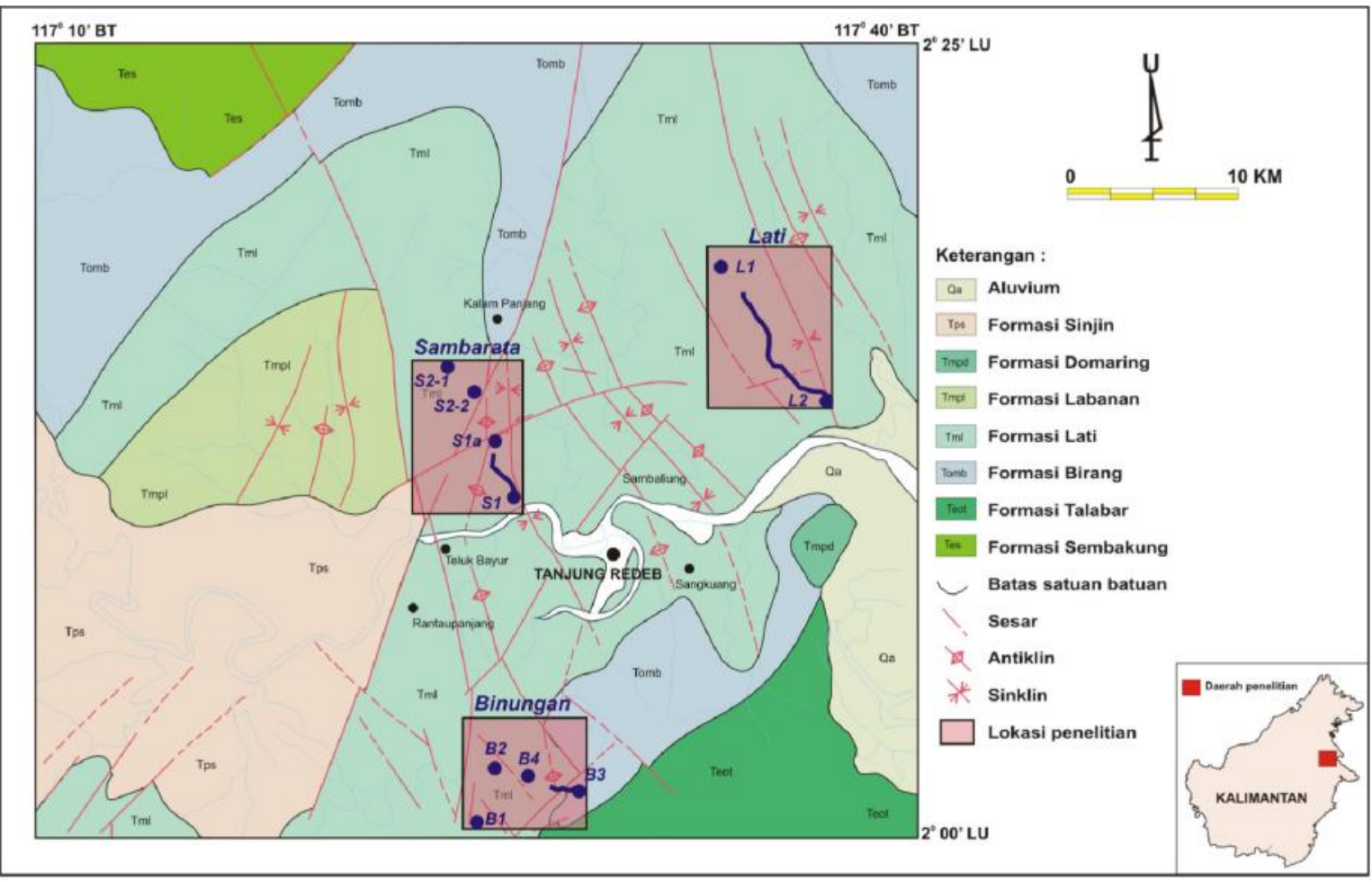

Gambar 2. Peta geologi daerah sekitar Berau, Kalimantan Timur (Situmorang \& Burhan, 1995) dan lokasi pengukuran stratigrafi rinci (Rachmansjah drr., 2003).

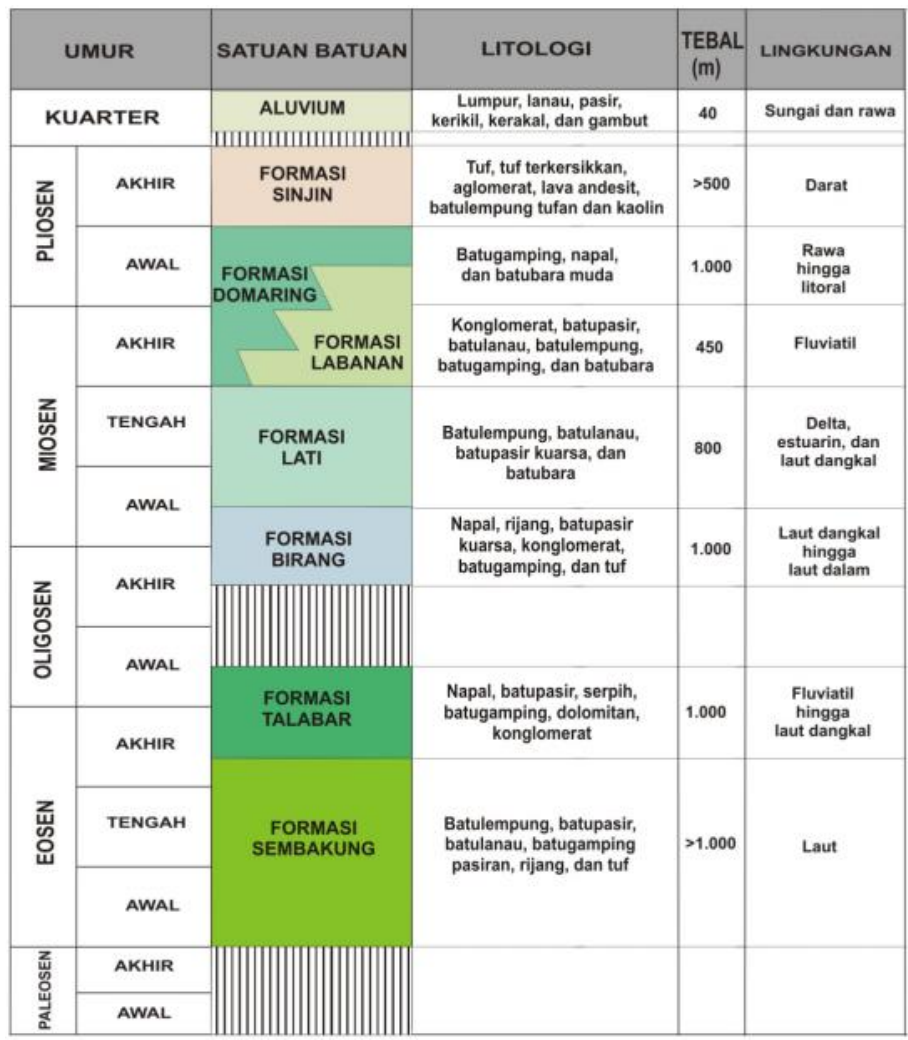

Gambar 3. Stratigrafi daerah sekitar Berau, Kalimantan Timur menurut Situmorang \& Burhan (1995) dengan modifikasi. 


\section{STRATIGRAFIFORMASI LATI}

Dari salah satu formasi tersebut di atas, satuan batuan yang berfungsi sebagai batuan pembawa batubara adalah Formasi Lati. Bagian atas Formasi Lati ini terendapkan di lingkungan sungai hingga dataran delta yang berpotensi membawa lapisan batubara (Suwarna \& Hermanto, 2007). Batubara yang terkandung pada formasi ini secara umum layak tambang karena nilai pembakarannya mencapai lebih dari $5.600 \mathrm{kal} / \mathrm{gr}$ (Annonim, 1983; 1988).

Data stratigrafi rinci Formasi Lati di daerah penelitian didapatkan berdasarkan hasil pengukuran stratigrafi rinci di tiga lokasi, meliputi Lintasan Lati, Lintasan Binungan dan Lintasan Sambarata (Rachmansyah drr., 2003), dengan ketebalan total terukur mencapai 400 meter, yang ditindaklanjuti dengan pembahasan proses sedimentologi formasi ini (Maryanto drr., 2005).

Lintasan Lati berlokasi sekitar $20 \mathrm{~km}$ sebelah timurlaut Tanjungredeb, tebal stratigrafi terukur mencapai 280 meter, terbagi menjadi empat segmen stratigrafi dan mewakili seluruh bagian formasi (Gambar 4).

Runtunan batuan diawali dengan hadirnya batulumpur gampingan dengan sisipan batupasir dan batupasir gampingan, yang mewakili fasies delta bawah (prodelta). Di bagian tengah runtunan, batuan berkembang menjadi perlapisan batupasir dan batupasir gampingan dengan sisipan batulumpur, yang mewakili fasies delta depan (delta front). Fasies delta depan ini tidak terlalu tebal dan segera berganti menjadi fasies dataran delta yang merupakan bagian atas formasi. Bagian atas runtunan stratigrafi, yang mewakili fasies dataran delta (delta plain) terdiri atas batulumpur dan batulempung dengan sisipan batupasir yang kadang-kadang masih bersifat gampingan, serpih batubaraan dan batubara.

Lintasan Binungan berlokasi sekitar 30 $\mathrm{km}$ sebelah baratdaya Tanjungredeb, tebal stratigrafi terukur mencapai 300 meter, dan terbagi menjadi lima segmen stratigrafi dan mewakili seluruh bagian formasi (Gambar 5).

Bagian bawah runtunan stratigrafi terdiri atas batulempung gampingan, batulumpur gampingan, sisipan batupasir, batupasir gampingan dan batugamping. Bagian tengah runtunan stratigrafi kurang teramati dengan baik dan hanya merupakan sedikit batuan yang terendapkan pada fasies delta depan. Batuannya terdiri atas batulumpur sedikit karbonan dan gampingan, sisipan batupasir, yang segera berkembang menjadi perlapisan batupasir dengan sedikit sisipan batulumpur. Bagian atas formasi terdiri atas batulumpur yang kadang berkembang menjadi serpih batubaraan dan batulempung, sisipan batupasir dan batubara. Batulumpurnya sering sangat karbonan di bagian atas lapisan hingga disebut sebagai serpih batubaraan.

Lintasan Sambarata berada sekitar 15 $\mathrm{km}$ sebelah barat Tanjungredeb, tebal stratigrafi terukur mencapai 300 meter, terbagi menjadi tiga segmen stratigrafi yang mewakili bagian tengah dan atas formasi (Gambar 6). Runtunan batuan diawali oleh hadirnya batulumpur, batulempung, batupasir, sisipan serpih batubaraan dan batubara. Runtunan batuan berulang hingga beberapa kali dan sisipan batubara semakin banyak dijumpai dengan ketebalan cukup berarti.

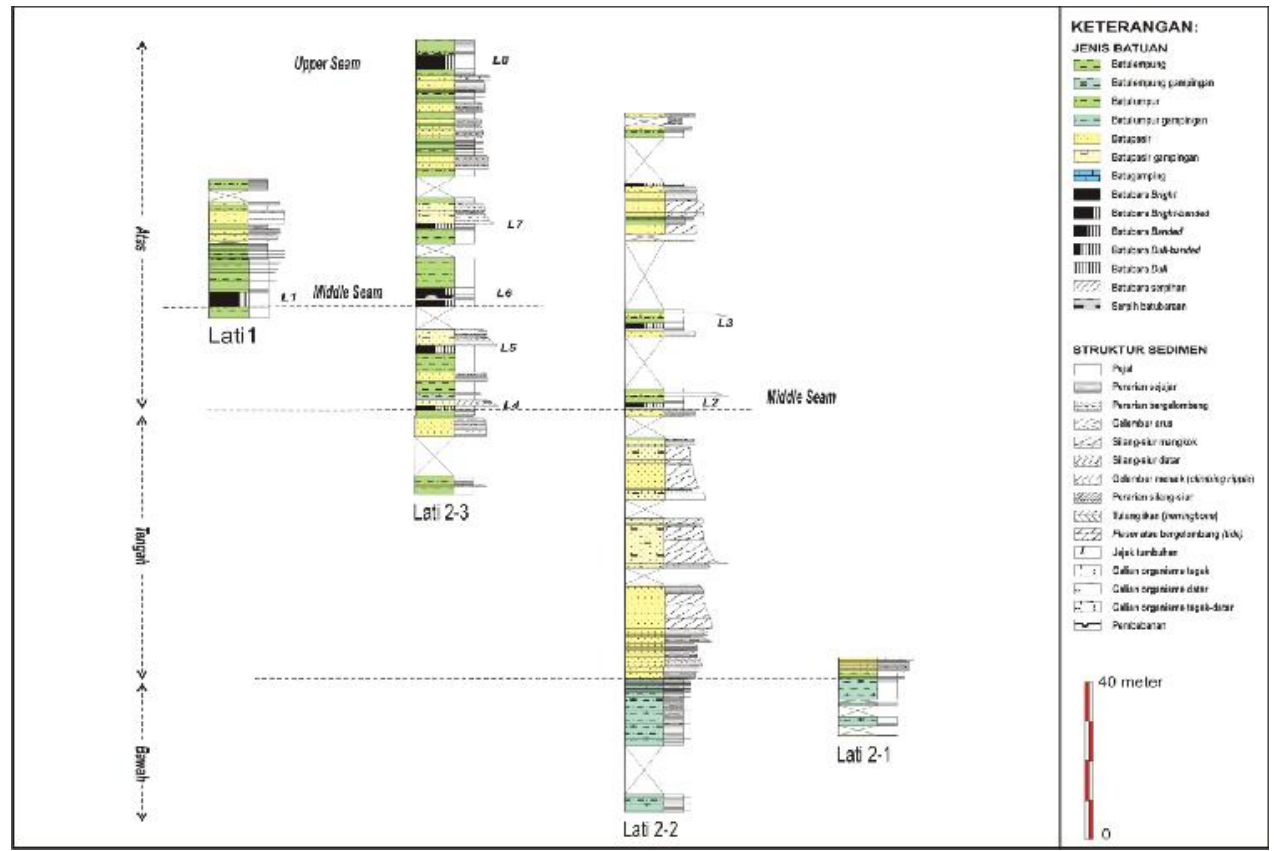

Gambar 4. Kolom stratigrafi terukur di Lintasan Lati, Berau, Kalimantan Timur (Rachmansjah drr., 2003). 


\section{MAKALAH ILMIAH}

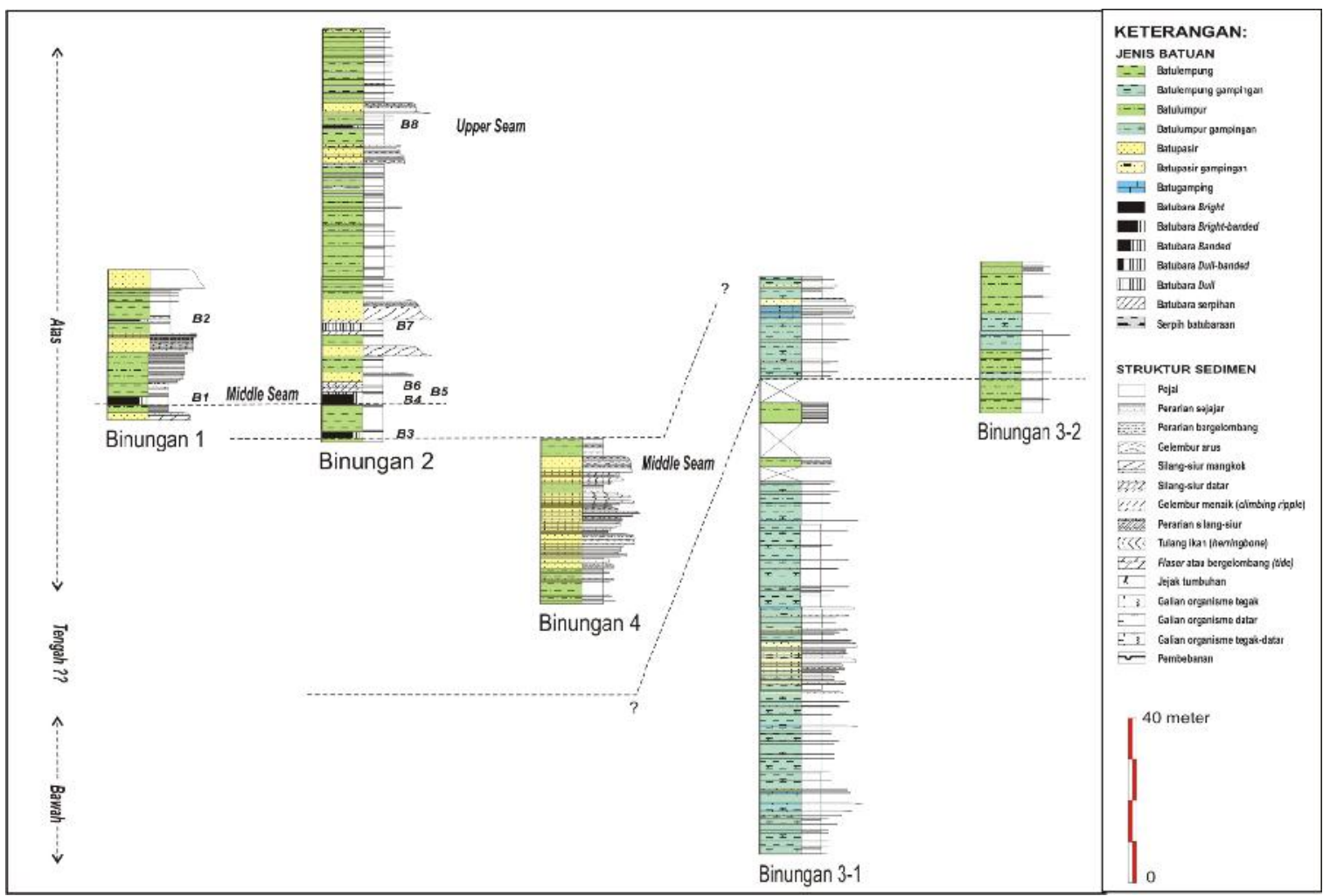

Gambar 5. Kolom stratigrafi terukur di Lintasan Binungan, Berau, Kalimantan Timur (Rachmansjah drr., 2003).

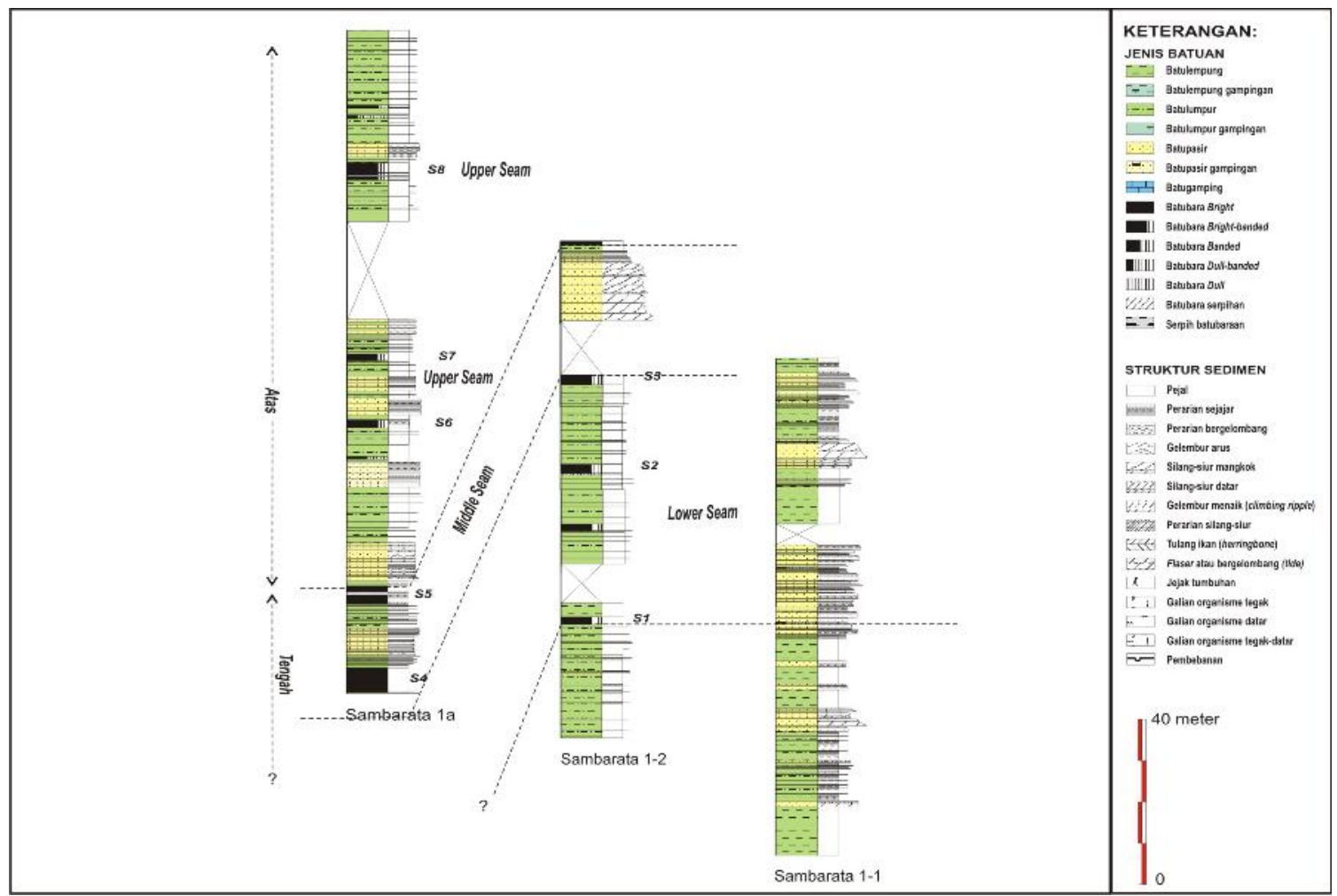

Gambar 6. Kolom stratigrafi terukur di Lintasan Sambarata, Berau, Kalimantan Timur (Rachmansjah drr., 2003) 


\section{KETERDAPATAN BATUBARA}

Beberapa perlapisan batubara dijumpai di Formasi Lati. Secara umum batubara yang dijumpai terbagi menjadi tiga perlapisan (berdasarkan korelasi bawah permukaan, Annonim, 1983), meliputi perlapisan bawah (lower seams), perlapisan tengah (middle seams), dan perlapisan atas (upper seams).

\section{Perlapisan Batubara Bawah}

Batubara perlapisan bawah (lower seams) secara stratigrafi relatif masih berada di bagian tengah formasi. Korelasi antar lintasan stratigrafi (Gambar 7) menunjukkan bahwa batubara perlapisan bawah hanya dijumpai di Lintasan Sambarata, sedangkan di dua lintasan stratigrafi lainnya tidak dijumpai. Batuan di dua lintasan tersebut masih berupa batulumpur gampingan dan batulumpur dari fasies delta bawah, dengan beberapa sisipan batupasir mengasar ke atas dari fasies delta depan, yang beberapa bagian dipotong oleh batupasir berlapis susun dan silang-siur dari fasies saluran delta.

Perlapisan batubara bawah dicirikan warna hitam, cerat coklat gelap, bright-banded, terkekarkan, pecah subkonkoidal, densitas sedang, tebal $160-260 \mathrm{~cm}$ yang bagian bawah lapisannya kusam menyerpih dan mudah hancur, begitu pula bagian atas lapisan. Parting batupasir sangat halus berketebalan $20-40 \mathrm{~cm}$ dijumpai di dalam perlapisan batubara bagian bawah ini.

\section{Perlapisan Batubara Tengah}

Batubara perlapisan tengah (middle seams) hadir di semua lintasan stratigrafi, merupakan perlapisan utama, berkedudukan pada bagian atas formasi. Perlapisan batubara tengah diawali dengan hadirnya lapisan batubara di Lintasan Lati. Perlapisan batubara tengah selanjutnya berkembang sangat baik di ketiga lintasan stratigrafi. Korelasi stratigrafi yang dilakukan didasarkan atas kehadiran perlapisan batubara tengah ini dengan penciri hadirnya lempung kaolinit di bawah dan atas lapisan (Annonim, 1983; 1988).

Perlapisan batubara tengah dicirikan dengan warna coklat gelap kehitaman, cerat coklat, mudah hancur, terkekarkan, densitas sedang hingga tinggi, banded dan tebalnya 120$200 \mathrm{~cm}$. Dalam batubara ini terdapat resin dan pirit, bagian atasnya menyerpih, terdapat parting batupasir $5 \mathrm{~cm}$ (Gambar 9). Ke arah atas, perlapisan batubara menjadi lebih coklat gelap kehitaman, cerat coklat, banded, terkekarkan mudah hancur, densitas sedang, tebalnya 100$350 \mathrm{~cm}$, bagian bawah dan atasnya berupa serpih batubaraan, masih mengandung pirit, terdapat parting batulempung dan batulempung tufan setebal $5 \mathrm{~cm}$.

Perlapisan batubara pada umumnya dicirikan dengan warna hitam hingga hitam kecoklatan (Gambar 10), cerat coklat gelap, bright-banded, terkekarkan, pecah subkonkoidal, densitas sedang, berketebalan lapisan $120-535 \mathrm{~cm}$, serta masih terdapat pirit meskipun jumlahnya sangat terbatas. Bagian atas perlapisan batubara ini sering berkembang menjadi batubara serpihan hitam kecoklatan, cerat coklat, kusam, terkekarkan, mudah hancur, dapat diremas, dan tebalnya $80-110 \mathrm{~cm}$.

Pengulangan lapisan berikutnya merupakan akhir pengendapan perlapisan batubara tengah. Perlapisan batubara yang dijumpai tampak berwarna hitam, cerat coklat gelap, bright-banded, terkekarkan, pecah subkonkoidal, densitas sedang, masih mengandung pirit, tebal lapisan mencapai 240 $\mathrm{cm}$ yang menipis hingga $30 \mathrm{~cm}$, dan dialasi oleh batulumpur karbonan. Batupasir berstruktur gelembur arus (Gambar 11) kadang-kadang menindih perlapisan batubara bagian tengah ini.

\section{Perlapisan Batubara Atas}

Perlapisan batubara atas (upper seams) kebanyakan dijumpai di Lintasan Sambarata, sedangkan di Lintasan Lati dan Lintasan Binungan dijumpai sangat terbatas. Lapisan batubara umumnya berwarna hitam sedikit kecoklatan, cerat coklat, banded hingga brightbanded, mudah hancur, terkekarkan, pecah subkonkoidal, densitas sedang dan tebalnya 200 $\mathrm{cm}$ yang menipis hingga $30 \mathrm{~cm}$. Pengulangan perlapisan batubara atas hanya dijumpai di Lintasan Sambarata.

Perlapisan batubara yang dijumpai tampak berwarna hitam, cerat coklat kehitaman, bright hingga bright-banded, pecah subkonkoidal, mudah hancur, terkekarkan, mengandung resin dan sangat jarang pirit, densitas sedang - rendah, tebal perlapisan 70$650 \mathrm{~cm}$ dengan beberapa parting batubara serpihan, bagian bawah dan atas lapisannya berupa serpih batubaraan yang berwarna hitam kecoklatan, mudah hancur, kusam dan lumpuran. Batuan di antara perlapisan batubara tersebut pada umumnya berupa batulumpur dan batulempung dengan sisipan tipis batupasir halus hingga sangat halus berstruktur perarian sejajar. 


\section{MAKALAH ILMIAH}

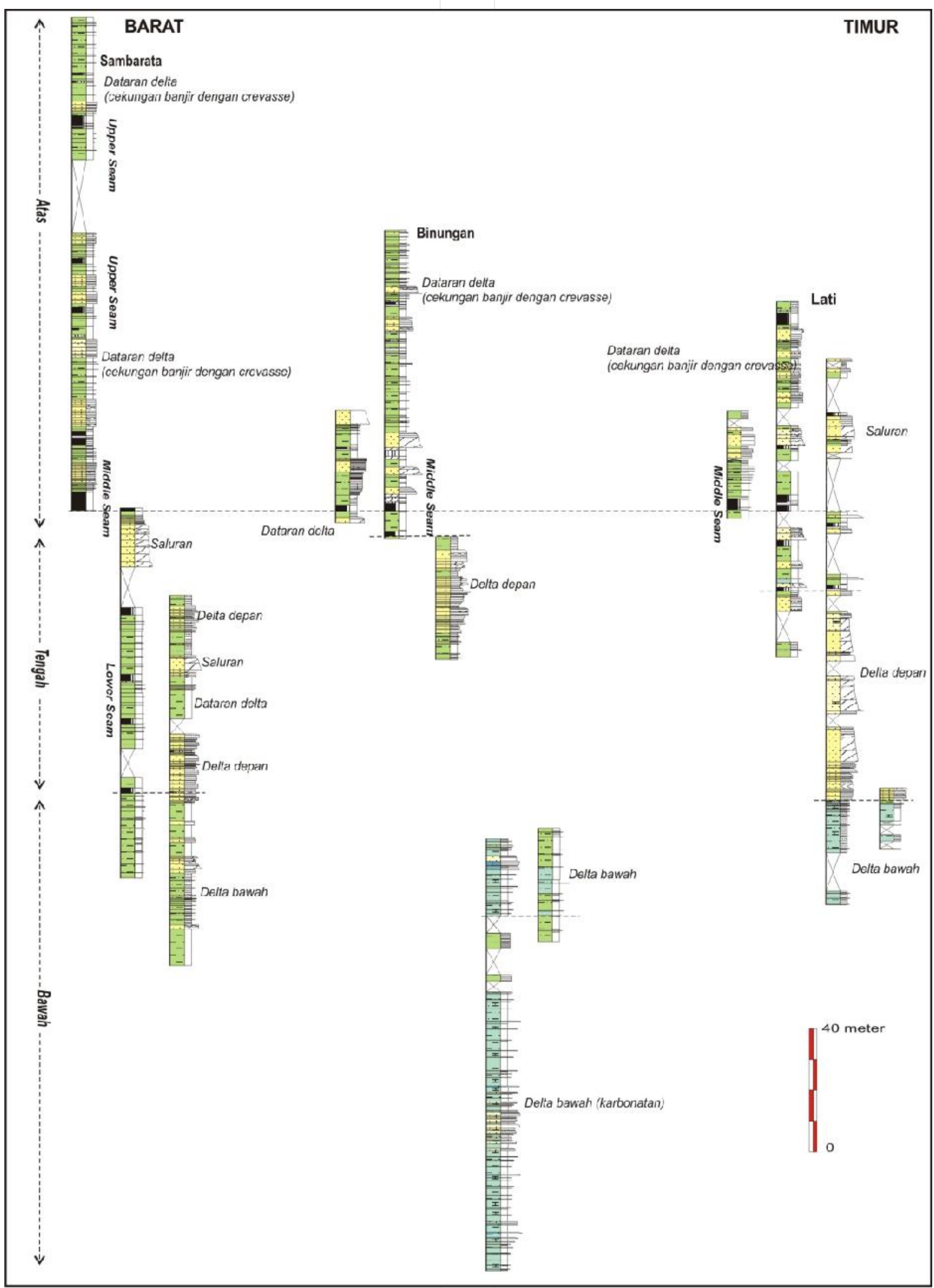

Gambar 7. Korelasi stratigrafi antar lintasan pada Formasi Lati di Berau, Kalimantan Timur. 


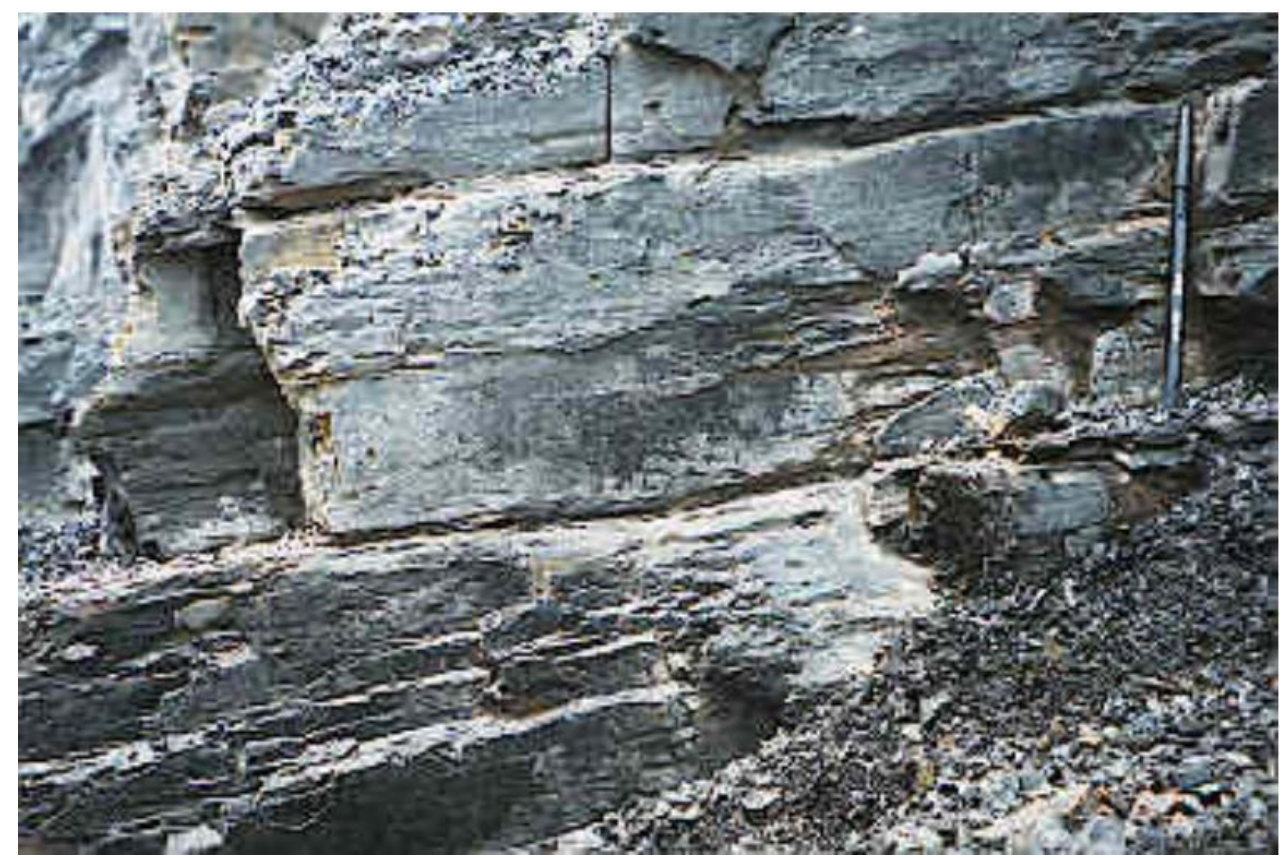

Gambar 8. Salah satu batubara perlapisan tengah yang berwarna coklat gelap kehitaman dengan densitas sedang. Difoto di Stasiun 0, Lintasan Lati (Maryanto drr., 2005).

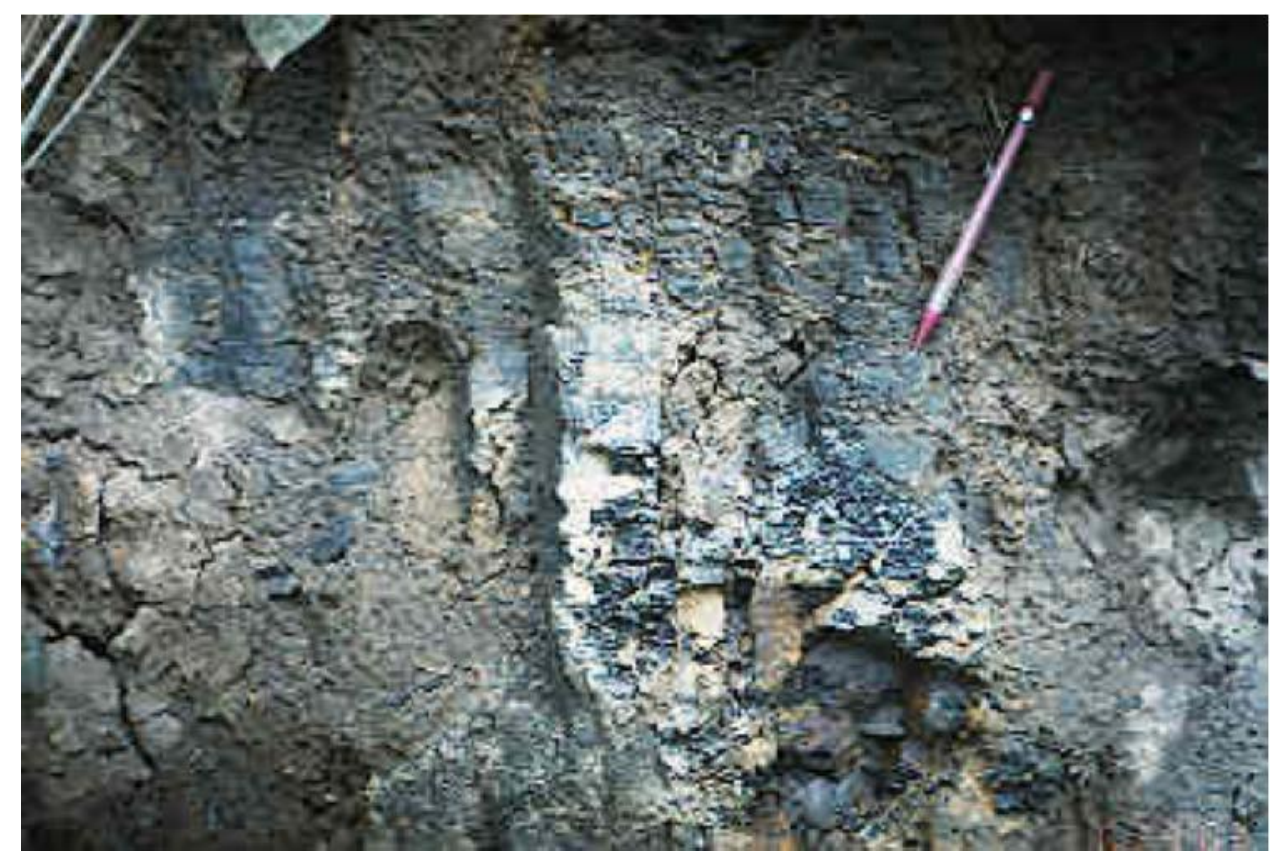

Gambar 9. Batubara perlapisan tengah yang berwarna hitam kecoklatan, bright banded, dan sedikit terkekarkan. Difoto di Stasiun 5-6, Lintasan Binungan (Rachmansjah drr., 2003). 


\section{MAKALAH ILMIAH}

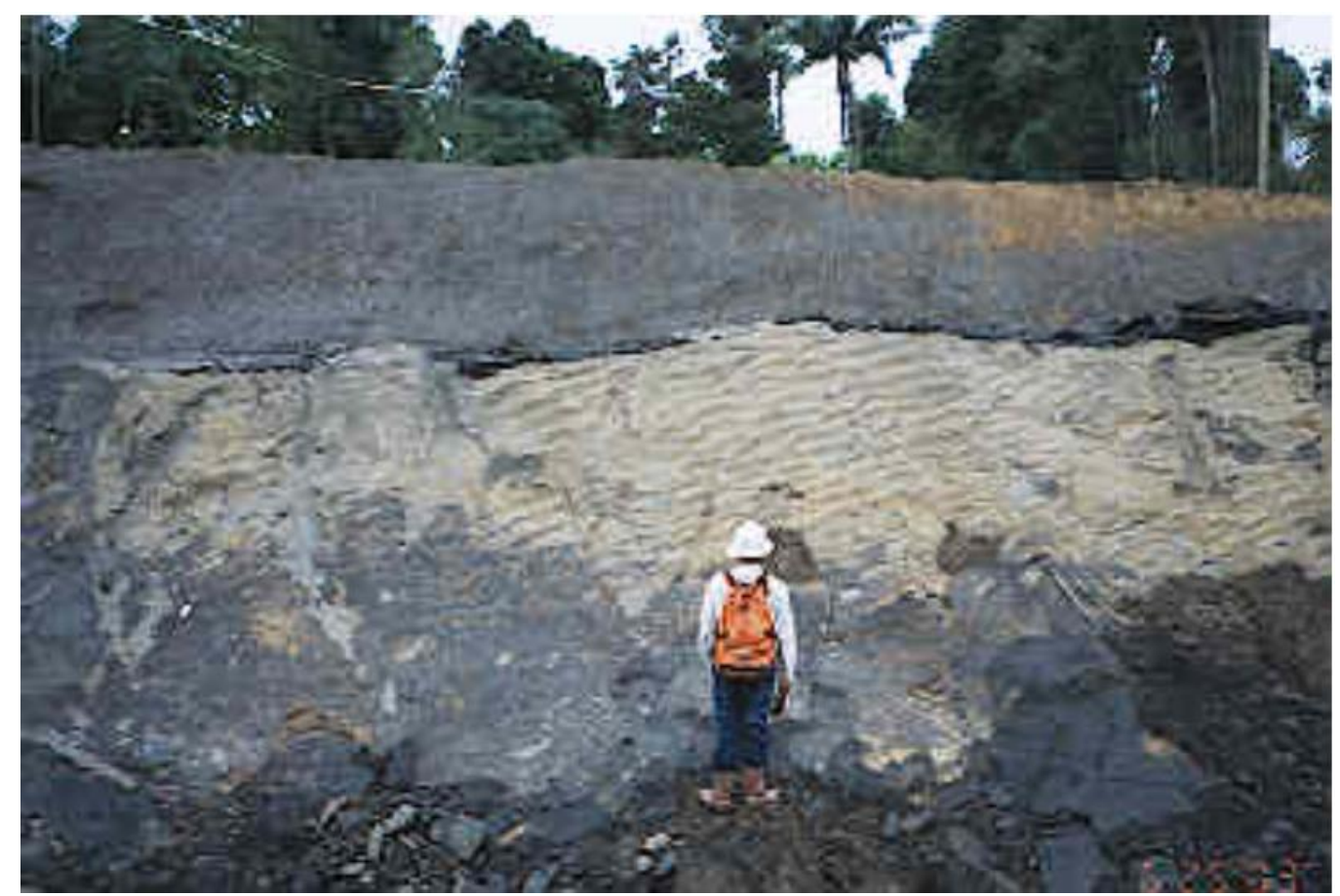

Gambar 10. Struktur gelembur arus pada batupasir yang mengerosi perlapisan batubara perlapisan tengah. Difoto di Stasiun 21-22, Lintasan Sambarata (Rachmansjah drr., 2003).

\section{PENGUJIAN LABORATORIUM}

Analisis kimia telah dilakukan terhadap dua belas sampel batubara. Hasil analisis kimia batubara yang telah dilakukan (Tabel 1) menunjukkan bahwa kandungan zat terbang $20,40-39,01 \%$, karbon padat $20,11-45,60 \%$, abu $1,33-51,77 \%$, belerang $0,18-3,39 \%$, nilai kalori 2.265-5.927 kal/gr, air lembab 8,28-21,26\%, dan air total 8,33-18,60\%.

Analisis palinologi telah dilakukan terhadap tujuh sampel batubara, batubara serpihan dan serpih batubaraan (Tabel 2). Berdasarkan asosiasi palinomorf yang ada dapat dikatakan bahwa kisaran umur batuan adalah Miosen Tengah, dengan lingkungan pengendapan mulai dari air tawar, rawa gambut air tawar, rawa gambut air payau, hingga rawa air payau.

Analisis petrografi dilakukan terhadap dua puluh empat sampel batubara (Tabel 3), memperlihatkan komponen batubara terdiri atas vitrinit 70,6-92,0 \%, inertinit 0,2-14,2\%, eksinit 0$9,2 \%$, pirit $0-11,6 \%$, karbonat $0-8,8 \%$ dan mineral lempung $0-10,6 \%$. Nilai reflektan vitrinit minimun $0,27-0,46 \%$, nilai reflektan vitrinit maksimum $0,39-0,56 \%$, dan nilai reflektan vitrinit rata-rata $0,31-0,51 \%$.

\section{PEMBAHASAN}

Perlapisan batubara pada Formasi Lati di daerah Berau, Kalimantan Timur mulai hadir di bagian tengah formasi, yaitu di Lintasan Sambarata. Perlapisan batubara di lintasan ini (lower seams) dijumpai dengan jumlah dan tebal terbatas. Keterbatasan ini sangat dipengaruhi oleh kedudukan lingkungan pengendapan pada saat itu. Secara umum kedudukan lingkungan pengendapan sangat mempengaruhi ketebalan, bentuk, penyebaran, dan mutu lapisan batubara (Papp et al., 1998). Bagian tengah Formasi Lati secara umum masih terendapkan di lingkungan delta depan hingga dataran delta khususnya di Lintasan Sambarata (Maryanto drr., 2005). Dengan demikian fase pengendapan batubara masih sangat terpengaruh oleh air laut, dicirikan dengan mineral karbonat yang masih cukup banyak. Keadaan lingkungan pengendapan di dua lintasan lainnya pada saat itu masih berada di delta depan hingga delta bawah yang tidak memungkinkan terbentuknya perlapisan batubara.

Pada bagian atas formasi, keadaan susut laut yang membentuk Formasi Lati, dimana terkonsentrasi cukup banyak perlapisan batubara (middle seams), adalah dataran delta 
dengan pengaruh pasang-surut cukup kuat (Maryanto, drr., 2005), akan tetapi pengaruh fluvial masih sangat dominan. Secara lebih khusus lingkungan pengendapan batubara ini berada di wilayah rawa gambut air tawar yang kadang-kadang menjadi payau akibat pasangsurut (Tabel 2). Lapisan batubara yang terkonsentrasi di bagian atas Formasi Lati, terbentuk di wilayah pusat cekungan dataran delta yang sekali waktu terpotong oleh endapan saluran menyebar (distributary channel). Batubara yang dijumpai mempunyai tebal terbatas dan lapisannya tercerai (splitting) karena terganggu oleh banjir limpah permukaan, jebolan tanggul (levee) dan pengaruh pasang-surut yang cukup intensif. Keadaan ini menyebabkan sulitnya melakukan korelasi stratigrafi antar lintasan yang jaraknya cukup jauh.

Bagian teratas Formasi Lati masih mempunyai sedikit perlapisan batubara (upper seams) dengan ketebalan terbatas. Dari data stratigrafi tampak bahwa lingkungan pengendapan bagian teratas formasi ini adalah cekungan lokal dataran delta yang sangat memungkinkan terbentuknya perlapisan barubara. Namun demikian, dijumpainya cukup banyak sisipan pasir halus hingga sangat halus dari fasies limpasan samping (crevasse splay; Bhattacharya, 1992) menyebabkan pembentukan lapisan batubara menjadi tidak optimal, dan mengurangi mutu batubaranya sendiri.

Batubara yang dijumpai di daerah sekitar Tanjungredep masih bermutu cukup bagus sebagai bahan tambang dan terbukti telah diekspor ke Korea dan Jepang. Formasi batuan pembawa batubara yang dijumpai di daerah penelitian secara umum berumur Tersier (Miosen Awal - Tengah). Dengan memperhatikan keadaan dan perubahan lingkungan pengendapan batuan dari umur tersebut hingga sekarang (Holosen), terlihat bahwa batuan sedimen yang menindih Formasi Lati cukup tebal (Gambar 3). Hal ini menunjukkan bahwa pematangan batubara di daerah penelitian berkaitan dengan gradien geotermal akibat penimbunan batuan sedimen di atas Formasi Lati.

Secara megaskopis, batubara di tiga daerah penelitian masih mengandung pirit berbutir halus framboidal dan berwarna kuning pucat. Pirit dalam batubara dapat menjadi salah satu petunjuk untuk melakukan interpretasi fasies dan lingkungan pengendapan batubara (Anggayana \& Widayat, 2007). Kandungan maseral vitrinit yang sangat dominan mencerminkan batubara yang terendapkan di lingkungan rawa-rawa pada hutan hujan (Teichmüller \& Teichmüller, 1982; Bustin et al., 1983) yang berada di dataran delta hingga sungai yang beriklim basah (Suwarna \& Hermanto, 2007). Hadirnya sejumlah kecil inertodetrinit, liptodetrinit dan mineral lempung menunjukkan bahwa lingkungan pengendapan sering terpengaruh oleh serbuan air laut (Stach et al., 1982, Teichmüller, 1982). Adanya material karbonat dan pirit framboidal pada setiap sampel yang dianalisis menunjukkan bahwa selama pengendapan batubara masih ada pengaruh pasang-surut, meskipun pengaruh fluvial yang dominan. Dengan adanya pengaruh pasangsurut ini maka bentuk delta Sungai Berau di sebelah timur daerah penelitian lebih mirip dengan delta di Teluk Papua yang merupakan delta pasang-surut (Bhattacharya, 1992; Dalrymple, 1992) dibandingkan dengan Delta Mahakam yang terpengaruh besarnya pemasukan material dan pasang-surut (Marks et al., 1982). Berdasarkan nilai reflektan vitrinit maksimum $0,56 \%$, batubara di daerah penelitian termasuk dalam batubara sub-bituminous B (penggolongan batubara menurut Teichmuller, 1982 dalam Hower et al, 1998). Apabila diperhatikan nilai vitrinit maksimum ini, terlihat tidak ada perbedaan yang menyolok di masingmasing sampel. Artinya, faktor tekanan beban merupakan faktor utama yang mempengaruhi proses pematangan batubara.

Berdasarkan hasil analisis kimia batubara terlihat bahwa anomali terjadi pada sampel L2-13 dan L2-18 yang nilai kalorinya rendah. Hal ini berkaitan dengan kedudukan lingkungan pengendapan yang berada di tepian cekungan lokal dataran delta. Sampel lainnya, kecuali kedua sampel tersebut di atas, tidak menunjukkan perbedaan yang menyolok. Keadaan ini mencerminkan bahwa pada saat pengendapan bahan pembentuk batubara maupun saat proses pembatubaraan bahan tersebut tidak dijumpai pengecualian proses geologi. Baik lingkungan pengendapan maupun proses pembatubaraan pada Formasi Lati nisbi seragam. Penyesaran, sebagai salah satu proses yang mempengaruhi pembatubaraan, tampaknya tidak berpengaruh di daerah penelitian, artinya hanya mempengaruhi perpindahan lokasi keterdapatan Iapisan batubaranya sendiri. 
Tabel 1.

Hasil uji kimia batubara di daerah Berau, Kalimantan Timur (Maryanto drr., 2005)

\begin{tabular}{|c|c|c|c|c|c|c|c|c|}
\hline NO. & $\begin{array}{c}\text { KODE } \\
\text { SAMPEL }\end{array}$ & $\begin{array}{c}\text { AIR } \\
\text { TOTAL } \\
\mathbf{\%}, \mathbf{a r}\end{array}$ & $\begin{array}{c}\text { AIR } \\
\text { LEMBAB } \\
\mathbf{\%}, \mathbf{a d b}\end{array}$ & $\begin{array}{c}\text { KADAR } \\
\text { ABU } \\
\mathbf{\%}, \mathbf{a d b}\end{array}$ & $\begin{array}{c}\text { ZAT } \\
\text { TEBANG } \\
\mathbf{\%}, \mathbf{a d b}\end{array}$ & $\begin{array}{c}\text { KARBON } \\
\text { PADAT } \\
\mathbf{\%}, \mathbf{a d b}\end{array}$ & $\begin{array}{c}\text { NILAI } \\
\text { KALOR } \\
\mathbf{c l} / \mathbf{g r}, \mathbf{a d b}\end{array}$ & $\begin{array}{c}\text { BELERANG } \\
\text { TOTAL } \\
\mathbf{\%}, \mathbf{a d b}\end{array}$ \\
\hline 1. & L1 (L1-02) & 17,79 & 17,65 & 2,75 & 37,66 & 41,94 & 5.474 & 3,39 \\
\hline 2. & L2 (L2-13) & 8,33 & 8,28 & 51,77 & 20,40 & 19,55 & 2.262 & 2,00 \\
\hline 3. & L4 (L2-18) & 21,26 & 15,58 & 24,57 & 34,06 & 20,11 & 2.265 & 0,43 \\
\hline 4. & L5 (L2-20) & 18,60 & 17,40 & 1,58 & 37,66 & 43,36 & 5.563 & 1,43 \\
\hline 5. & L7 (L2-22) & 16,35 & 15,93 & 4,06 & 37,85 & 42,16 & 5.580 & 1,56 \\
\hline 6. & L8 (L2-25) & 16,14 & 15,98 & 4,48 & 36,51 & 43,03 & 5.340 & 0,89 \\
\hline 7. & B1 (B1-01) & 15,27 & 14,92 & 2,18 & 38,66 & 44,24 & 5.927 & 0,22 \\
\hline 8. & B3 (B2-01) & 14,68 & 14.41 & 1,33 & 38,66 & 45,60 & 5.878 & 1,10 \\
\hline 9. & B5 (B2-05) & 14,02 & 13,72 & 3,33 & 39,01 & 43,94 & 5.850 & 0,18 \\
\hline 10. & B6 (B2-07) & 14,70 & 14,37 & 4,62 & 37,50 & 43,51 & 5.708 & 0,29 \\
\hline 11. & B7 (B2-13) & 15,32 & 15,20 & 1,47 & 38,42 & 44,91 & 5.809 & 0,55 \\
\hline 12. & B8 (B2-20) & 11,56 & 11,25 & 11,56 & 37,38 & 39,81 & 5.319 & 1,58 \\
\hline
\end{tabular}

Tabel 2.

Hasil uji palinologi Formasi Lati di daerah Berau, Kalimantan Timur (Maryanto drr., 2005)

\begin{tabular}{|c|c|c|c|c|c|c|c|c|}
\hline \multirow{2}{*}{ PALINOMORF } & \multicolumn{8}{|c|}{ KODE SAMPEL } \\
\hline & B1-05 & B2-03 & B2-12 & B2-14 & B2-18 & L2-14 & L2-23 & L2-24 \\
\hline Anacolocidites & - & - & - & - & - & - & 1 & 1 \\
\hline Casuarina & 4 & - & 1 & - & - & - & 1 & - \\
\hline Dicolpopollis malesianus & 1 & 2 & 1 & - & 2 & - & - & 1 \\
\hline Discoidites borneensis & 1 & - & - & 2 & 3 & - & - & - \\
\hline Durio & 25 & 2 & 2 & 3 & 1 & - & - & - \\
\hline Eugenia & 2 & 2 & 8 & 9 & 1 & 1 & - & 1 \\
\hline Florscheutzia lepivoli & - & - & 10 & - & - & - & - & - \\
\hline Florscheutzia meridionales & - & 2 & 1 & - & 2 & - & - & - \\
\hline Florscheutzia trilobata & - & - & 10 & - & - & - & - & - \\
\hline Marginipollis consinus & 2 & 1 & 2 & - & - & - & - & 1 \\
\hline Palaquium & 2 & - & 6 & - & - & - & 1 & - \\
\hline Palmaepollenites & 5 & - & 6 & 6 & 10 & - & 2 & 9 \\
\hline Pinus & - & - & - & - & 1 & 1 & - & 1 \\
\hline Pometia & 3 & - & 14 & 1 & 1 & - & 2 & - \\
\hline Rhizophora & 1 & 2 & - & - & 1 & 18 & - & 2 \\
\hline Rubiaceae & 3 & - & 4 & 1 & - & - & - & - \\
\hline Spinizonocostites echinatus & - & 2 & - & - & - & - & - & - \\
\hline Verrucatosporites usmensis & 14 & 5 & 6 & 8 & 7 & - & 25 & 28 \\
\hline Verrucosisporites & - & - & - & - & - & - & 13 & - \\
\hline Big Psilatriletespore & 6 & 10 & 6 & 8 & 10 & - & 9 & 9 \\
\hline Big Retitriletespore & - & 10 & 8 & 1 & - & - & 10 & 12 \\
\hline Triletespore & - & 4 & 1 & - & - & 1 & - & 10 \\
\hline Monoletespore & - & 4 & 2 & 1 & - & - & - & - \\
\hline Trileteechinatespore & - & - & 1 & - & - & - & - & - \\
\hline $\mathrm{Um} \mathrm{ur}$ & - & $\begin{array}{l}\text { Miosen } \\
\text { Tengah }\end{array}$ & \begin{tabular}{|l|} 
Miosen \\
Tengah \\
\end{tabular} & - & $\begin{array}{l}\text { Miosen } \\
\text { Tengah }\end{array}$ & - & - & - \\
\hline $\begin{array}{l}\text { Lingkungan } \\
\text { pengendapan }\end{array}$ & $\begin{array}{c}\text { Rawa } \\
\text { gambut } \\
\text { air } \\
\text { tawar }\end{array}$ & $\begin{array}{c}\text { Rawa } \\
\text { gambut } \\
\text { air tawar }\end{array}$ & $\begin{array}{c}\text { Rawa } \\
\text { air } \\
\text { payau }\end{array}$ & $\begin{array}{c}\text { Air } \\
\text { tawar }\end{array}$ & $\begin{array}{c}\text { Air } \\
\text { tawar }\end{array}$ & $\begin{array}{c}\text { Rawa } \\
\text { gambut } \\
\text { air payau }\end{array}$ & \begin{tabular}{|c|} 
Rawa \\
gambut \\
air \\
tawar \\
\end{tabular} & $\begin{array}{c}\text { Rawa } \\
\text { gambut } \\
\text { air } \\
\text { tawar }\end{array}$ \\
\hline
\end{tabular}




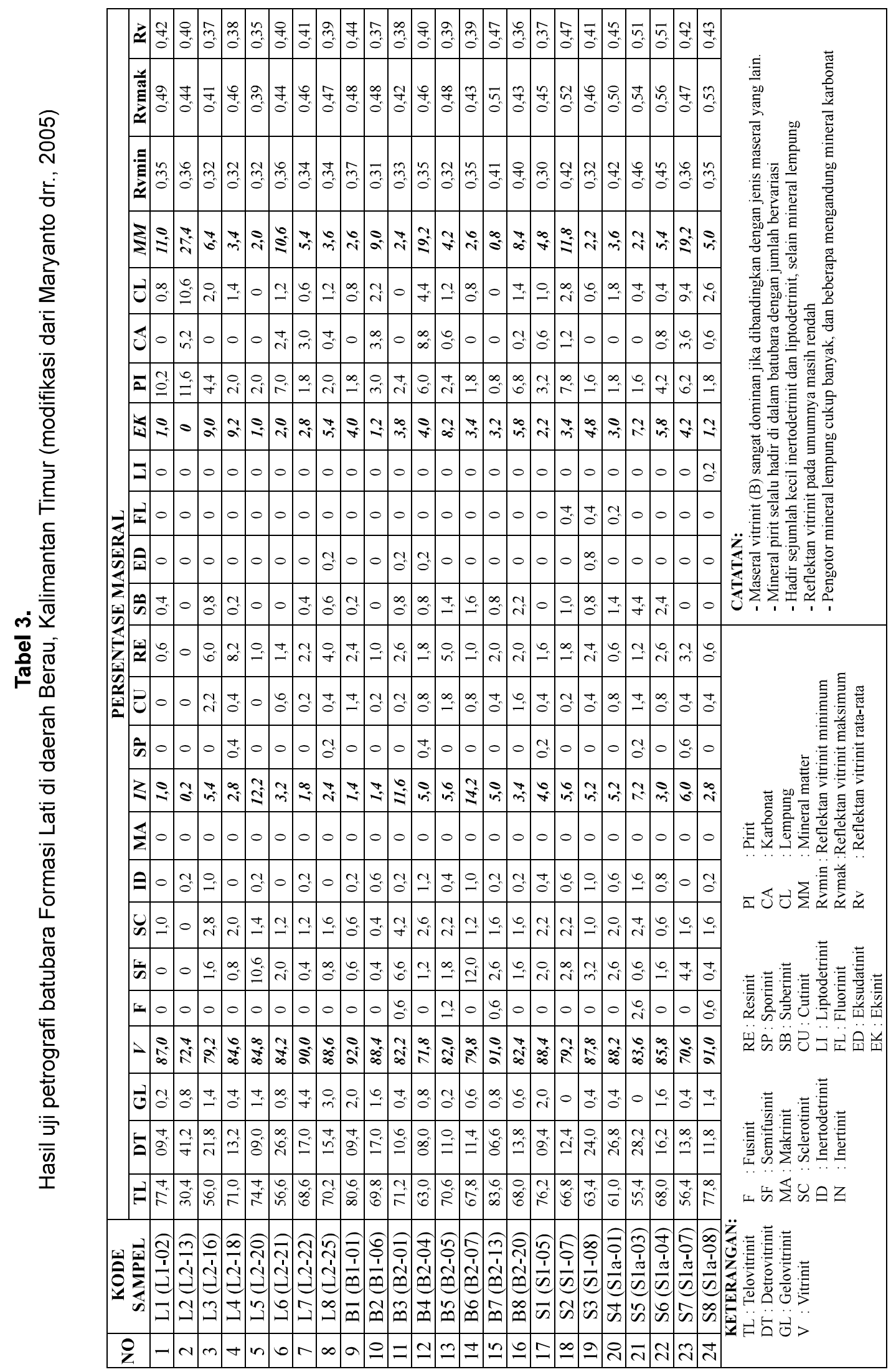




\section{KESIMPULAN}

Berdasarkan data stratigrafi di lintasan Lati, Binungan dan Sambarata, yang didukung oleh analisis laboratorium, dapat disimpulkan bahwa:

1. Perlapisan batubara di daerah Berau, Kalimantan Timur mulai hadir di bagian tengah Formasi Lati yang membentuk perlapisan batubara bawah, mencapai puncaknya pada bagian atas formasi ini yang membentuk perlapisan batubara tengah, dan menjadi sangat berkurang di bagian teratas formasi yang membentuk perlapisan batubara atas.

2. Perlapisan batubara terbentuk di lingkungan rawa-rawa pada hutan hujan yang berada di dataran delta hingga sungai beriklim basah pada kala Miosen Tengah.
3. Batubara yang dijumpai tidak terlalu tebal karena sering terganggu oleh banjir limpah permukaan dan terpengaruh oleh pasang-surut. Lapisan batubara tersebut pada umumnya melampar cukup luas, meskipun lapisannya seringkali tercerai, karena saluran deltanya nisbi sedikit bergeser dari waktu ke waktu.

\section{UCAPAN TERIMAKASIH}

Pada kesempatan ini diucapkan terima kasih kepada Ir. Jeffrey Mulyono, M.Sc. beserta ahli geologi PT. Berau Coal atas ijin penerbitan makalah dan bantuan pengumpulan data di lintasan stratigrafi rinci di wilayah penambangan.

\section{DAFTAR PUSTAKA}

Anggayana, K. dan Widayat, A.H., 2007. Interpretasi Fasies/Lingkungan Pengendapan Batubara dan Variasi Sulfur untuk Rekomendasi Strategi Eksplorasi. Kasus: Seam R, Daerah Lati, Sub-cekungan Berau, Cekungan Tarakan. Jurnal Geoaplika v. 2, n. 1, h. 3552.

Annonim, 1983. Berau Coal Area, Kalimantan, Indonesia. Internal Report Prepared for PT. Berau Coal Indonesia.

Annonim, 1988. Coal Exploration result of Lati Area DU424/Kaltim PT. Berau Coal. Indonesia. Internal Report Prepared for PT. Berau Coal Indonesia.

Bhattacharya, J.P. and Walker, R.G., 1992. Deltas, in Walker, R.G. and James, N.P. (eds), Facies Models, Response to Sea Level Change. Geological Association of Canada, pp. 157-177.

Bustin, R.M., Cameron, A.R., Grive, A.D., and Kalkreuth, W.D., 1983. Coal Petrology - Its Principles, Methods, and Applications. Geological Association of Canada, 230 p.

Dalrymple, R.W., 1992. Tidal Depositional System, in Walker, R.G. and James, N.P. (eds), Facies Models, Response to Sea Level Change. Geological Association of Canada, pp. 195-218.

Hower, J.C., Stanton, R.W., Gammidge, L.C., and Hutton, A.C., 1998. Coal Petrology, in Papp, A.R., Hower, J.C., and Hutton, A.C. (eds): Atlas of Coal Geology, Volume II, Energy Minerals Division, American Association of Petroleum Geologist.

Marks, E., Sujatmiko, Samuel, L., Dhanutirto, H., Ismoyowati, T., and Sidik, B.B., 1982. Cenozoic Stratigraphic Nomenclature in East Kutai Basin, Kalimantan, 11th Annual Convention of Indonesian Petroleum Association, Jakarta, $31 \mathrm{p}$.

Maryanto, S., Rachmansjah, Sihombing, T., dan Wiryosujono, S., 2005. Sedimentologi Batuan Pembawa Batubara Formasi Lati di Lintasan Lati, Berau, Kalimantan Timur. Jurnal Sumber Daya Geologi, v. 15, n. 4, h. 33-48.

Papp, A.R., Ayers, W.B., and Shattuck, P.J., 1998. Coal Geology, in Papp, A.R., Hower, J.C., and Hutton, A.C. (eds): Atlas of Coal Geology, Volume I, Energy Minerals Division, American Association of Petroleum Geologist.

Rachmansjah, Wiryosujono, S., Sihombing, T., dan Maryanto, S., 2003. Stratigrafi dan Sedimentologi Cekungan Batubara Tarakan, Kalimantan Timur. Laporan Teknis Intern, Pusat Penelitian dan Pengembangan Geologi, Bandung. 


\section{MAKALAH ILMIAH}

Situmorang, R.L. dan Burhan, G., 1995. Peta Geologi Lembar Tanjungredeb, Kalimantan. Pusat Penelitian dan Pengembangan Geologi, Bandung.

Stach, E., Mackowsky, M.Th., Teichmüller, M., Taylor, G.H., Chandra, D., and Teichmüller, R., 1982. Stach's Textbook of Coal Petrology. Gebrüder Borntraeger, Berlin-Stuttgart, 535 p.

Suwarna, N., Hermanto, B., Sihombing, T., and Kusumah, K.D., 2006. Coalbed Methane Potential and Coal Characteristic in Lati Region, berau Basin, East Kalimantan. Indonesian Journal of Geology, v.1, n. 1, pp. 19-30.

Suwarna, N. and Hermanto, B., 2007. Berau Coal in East Kalimantan: Its Petrographics Characteristics and Depositional Environment. Indonesian Journal of Geology, v.2, n. 4, pp. 191-206.

Tossin, S. dan Kadir, R., 1996. Tipe Reservoir Sedimen Miosen Tengah di Sub-Cekungan Tarakan, Cekungan Tarakan, Kalimantan Timur. Proceeding of the 25th Annual Convention of The Indonesian Association of Geologist, pp. 495-512.

Teichmüller, M. and Teichmüller, R., 1982. Fundamental of Coal Petrology. In: Stach, E., Mackowsky, M.Th., Teichmüller, M., Taylor, G.H., Chandra, D., and Teichmüller, R. (eds.), Stach's Textbook of Coal Petrology. Gebrüder Borntraeger, Berlin, 3rd ed., 535 p.

Teichmüller, M., 1982. The Geological Basis of Coal Formation. In: Stach, E., Mackowsky, M.Th., Teichmüller, M., Taylor, G.H., Chandra, D., and Teichmüller, R. (Eds.), Stach's Textbook of Coal Petrology. Gebrüder Borntraeger, Berlin, 3rd ed., pp. 5-86. 